\title{
Assessment of Learning Outcomes in Higher Education: Review of Literature
}

\author{
Yohana Kifle Mekonen ${ }^{a}$, Rakotoarivelo Anja Fitiavana ${ }^{b}$ \\ ${ }^{a}$ Kyohana24@yahoo.com \\ Faculty of Education, Southwest University \\ Tiansheng Road, Beibei,Chongqing, 400715, China \\ b3471108630@qq.com \\ International College, Southwest University \\ Tiansheng Road, Beibei,Chongqing, 400715, China
}

\begin{abstract}
Globally, assessment is considered as indispensable component of all educational levels and its significance has been acknowledged. While the definition of assessment is bewildering, generally assessment is the systematic collection, review, and use of information about educational programs undertaken for the purpose of improving learning and development. Enhancement of students learning is the final destination of any approaches of assessment either formative assessment that is known as assessment for learning or summative assessment that is considered as assessment of learning discussed in this article. Hitherto, the traditional way of assessing students is regarded as highly judgmental with limited or no provision of feedback to students. The overall criticisms of traditional assessment that confined on attainment of certain knowledge and skills is believed to be insufficient for the current dynamic era. Accordingly, call for paradigm shift to more wide and meaningful way of assessment known as authentic assessment has been advocated. However, myriad challenges become a bottleneck for authentic assessment to take place essentially which the article revealed.
\end{abstract}

Keywords: assessment, learning outcomes, authentic, higher education

\section{Introduction}

Assessment of student learning has been getting more attention in the agendas of higher education still recently (Kuh, et al. 2014; Tremblay, Lalancette, \& Roseveare, 2012; Tractenberg, 2020) with controversies on single universal definition. The term assessment is used in several ways by diversified organizations and individuals with different goals (Banta, 2002; Serban, 2004) and different countries (Sadler, 2012). Thus, arises continuous debates and argument over giving definition (Ghaicha, 2016; James, 2010). However, generally assessment can be defined as a process with certain steps of collecting data, give meaning and interpretation that helps decisions to be made regarding individuals, groups or events (Ajayi, 2018; Kizlik, 2012). Similarly, Arustamyan, Siddikova, Sadullaeva, Solieva, \& Khasanova (2020) defined assessment as a process of measuring accomplishment of learning objectives at specific time of leaning process depend on prescribed standards. The same researchers clarified assessment process includes "identifying and analyzing the results" (p.573). To come to educational assessment, it is "systematic collection, review, and use of information about educational programs undertaken for the purpose of improving learning and development" (Palomba, \& Banta, 1999, p. 4). Similarly, Tosuncuoglu (2018) stated that the term educational assessment relates to monitoring of students learning outcomes against the expected objectives to be achieved. Educational assessments have enormous impact for the process of teaching and learning as it describe the aspects of learning to be credited formally (Baird, Andrich, Hopfenbeck, \& Stobart, 2017).

According to Nusche (2008) changes attained as a result of learning that can be measured in terms of accomplishment and upgrade of abilities can be considered as learning outcomes. Nevertheless, educational assessment is beyond merely monitoring as it includes feedback that is necessary for maximizing the outcome of 
educational effort (Ajayi, 2018). Assessment in Higher Educational Institutions (HEIs) has also come to incorporate the whole path of evaluating institutional effectiveness as well (Banta, \& Palomba, 2014).

Educational assessment, evaluation and measurement represent different meanings, however commonly used interchangeably (Ghaicha, 2016; Tosuncuoglu, 2018) and students tend to have difficulty of distinguishing them (Kizlik, 2012). According to the authors' definition; assessment is gathering information to monitor progress and to reach in decisions, evaluation represent the methods employed to determine whether expected objective attained or not, and measurement refers to set of procedures to deal with educational assessments. James (2010) stated educational assessment sometimes shares common themes of educational measurement and evaluation. Likewise, Sadler (2012) supported that assessment and evaluation have common conceptual ground and share similar interrelated histories. Mostly, assessment and evaluation used interchangeably as both are the main components of the teaching and learning process (Tosuncuoglu, 2018). In the same vein, assessment of learning outcomes in HEIs comprises student performance measurement at course, program and institutional level as effective assessment is aligned with vision and mission of institutions (Serban, 2004). This takes place via exams or continuous assessment that measures the knowledge acquired with in particular field of study (Zuzana Straková, 2015). Shortly, as Ewell (2007) stated approaches targeted for collecting information regarding students learning and/or to approve accomplishment level are regarded as learning outcomes. Hence, this article is aimed to review related literatures regarding assessment and challenges of assessment of learning outcomes in HEIs.

\section{Assessment Approaches in Higher Education Institutions}

Several researchers underline the vital role assessment played at all levels of education (Gerritsen-van Leeuwenkamp, Joosten-ten Brinke, \& Kester, 2019,Taras, 2008, \& Tosuncuoglu, 2018), though there is disputes upon the definitions and scope of several types and approaches of assessments (Hernández, 2012). According to time interval assessment take place and feedback given; assessment can be categorized as formative and summative. Researchers stated formative assessment is known as assessment for learning and summative assessment is considered as assessment of learning with the following distinctions (Hernández, 2012; Taras, 2008; Rawlusyk, 2018). Formative assessment is continuous and takes place throughout the academic period which utmost directly influence student learning (Tractenberg, 2020). It is supervision oriented and diagnostic by which regular feedback by teachers or students (peer) given based on the results. Exercises (home and class works), project, assignment, self /peer evaluation, portfolio, observation, laboratory works, practicum etc. are some of formative assessment tools. Unlike to the previous approach summative assessment is commonly carried out at the end of a course, semester or specific project (Tractenberg, 2020). Summative assessment is evaluative and judgmental which intended to allocate grades or score points. Test, exam, midterm and final term course paper are some of the instruments used for summative assessment. However, if consistent feedback that improves learning is given summative assessment can be formative assessment (Carless et al., 2011). Guangul, Suhail, Khalit, \& Khidhir (2020) underlined for selecting any assessment type it should be relied on solid criteria aligned with expected objectives to be achieved.

In HEIs formative and summative assessment strategies mostly used simultaneously if it is facilitated by consistent feedback (Hernández, 2012). Rawlusyk (2018) stated in HEIs provision of feedback is a common practice instructors used both during course time and at the end of the semester. Similarly, Taras (2005) noted among the assessments strategies used in higher education some are designed to be both formative and summative. In the same vein, Koka, Jurāne-Brēmane, \& Koḳe (2017) indicated feeding forward through continuous feedback is part and parcel of formative assessment that facilitates learning. The authors identified intentionally organized formative assessment also improves self-reflection and communication skills. Formative assessments' main target is quick detection of strength and weakness for better learning by focusing on areas of improvement whereas summative is commonly targeted for evaluating students based on certain prescribed criteria (Rawlusyk, 2018). Shortly, Hernández (2012) summarized "assessment is about grading and reporting student achievements and about supporting students in their learning; and continuous assessment often does both of those things. Therefore, 
continuous assessment practices generally have a formative function for learning and a summative function for certification" (p. 490).

\section{Advantages of Assessment}

Internationally, assessment is considered as indispensable component of all educational levels as educational institutions are engaged in designing and applying compulsory, optional or combination of both assessments (Ghaicha, 2016). Several researchers advocated the advantages of educational assessment as Bryan, \& Clegg (2019) apparently stated "whatever we may think, assessment has become the currency with which we trade" (p.1). In the same vein, Serban (2004) stated assessment contributes for improvement of teaching and learning as it continuously measure student's progress and Borghouts, Slingerland, \& Haerens (2017) noted assessment support students' learning process. Effective and appropriate assessment methods of learning foster active participation of students, and classroom assessment which is a common way of assessing students plays a principal role for comparing students to each other, checking whether students meet the standards and also to ensure that teaching is progressing in the line with the intended goals (Baxter, 1997, p.7 cited in Zuzana Straková, 2015). Likewise Ghaicha (2016) stated, "Instructors can use assessment to place students in a group for behavioral, social and/or instructional purposes" (p.215). Shortly, assessment utilize as investigation device to know what students gained concerning to what was expected (Baird, Andrich, Hopfenbeck, \& Stobart, 2017) which have strong linkage to teaching and learning practices (Borghouts, Slingerland, \& Haerens, 2017).

In HEIs assessment provides numerous advantages. According to Banta, \& Palomba (2014); it provide information of students as individuals, students as groups and aggregated information regarding single course as well as across courses. Moreover, it provides information concerning how effective and reliable the curriculum is in its entirety and accordingly to check whether students possess the knowledge and skill they should as graduates. ZlatkinTroitschanskaia, \& Shavelson (2019) stated that, consistent and valid information regarding students learning contributes for assessing the progress of educational and societal goals as policy makers of HEIs, academicians and public realized the significance of student learning assessment. Nonetheless, effective assessment that relies on careful selection incorporated with suitable procedures and right interpretation of students' achievement contributes for evaluating sustainability of curriculum, instructional tools as well as methods of teaching (Fook, \& Sidhu, 2010). "When assessment is integrated with in and during the learning experience be it course, workshop or conference, it can be used to make decisions about how best to teach in order to optimize student learning "(Tractenberg, 2020 p.3). Though assessments' main target is to improve teaching and learning some institutions' careful consideration of assessment is for improving image of the institution by attracting potential students and to get more funding and grant opportunities (Banta, \& Palomba, 2014). The same researchers asserted that, some institutions use assessment as a means of educational introspection that leads to self- analysis of examining accomplishment and failure. Furthermore, data collected via assessment serves as a clue for identifying ability, achievement and placement of students (Fook, \& Sidhu, 2010).

\section{Learning Outcomes in Higher Education}

HEIs learning outcome assessment is comparatively new and greatly important (Zlatkin-Troitschanskaia, \& Shavelson, 2019). Due to rapidly growing higher education context, need for clear and effective way of measuring students' actual learning outcomes remains significant task of education sector (Tremblay, Lalancette, \& Roseveare, 2012). Guangul, Suhail, Khalit, \& Khidhir (2020) stated HEI programs have specific learning outcomes.Learning outcomes refers to what students' achieved at the end of any engagement whether or not it's the intended objectives of the institution (Allan, 1996) that can be measured or detected through effective assessment tools. Ewell (2007) defined "outcome can be most broadly defined as something that happens to an individual student (hopefully for the better) as a result of her or his attendance at an institution of higher education and/or participation in a particular course of study" (p.3). 
Similarly, Banta, \& Palomba (2014) stated, “ over the past three decades, the term outcomes assessment in higher education has come to imply aggregating individual measures for the purpose of discovering group strengths and weaknesses that can guide improvement actions" (p.1). Outcomes-based approaches in higher education that initially introduced in the USA, Australia, New Zealand and UK and later in OECD countries (Adam, 2004), are not only limited to learning outcomes (Nusche, 2008). For instance, HEIs students apart from mastery of knowledge and skills expected to be achieved from the formal learning engagement, they become beneficial in various ways. Social prestige and status, better careers, higher opportunities for further studies and leading better life can be mentioned (Ewell, 2007), as implicit long term social and economic advantages of HEIs engagement (Nusche, 2008).

Assessment of Higher Education Learning Outcomes (AHELO) is one of the international organization facilitated by OECD relied on the above mentioned objective. AHELO assess students' attainment upon graduation at international scale (Tremblay, Lalancette, \& Roseveare, 2012). Similarly, Altbach (2015) stated, comparison of learning outcomes of various academia disciplines of different countries based on test results is another aim of AHELO. Kuh, Jankowski, Ikenberry, \& Kinzie (2014) noted that, clearly stated learning outcomes provide information to students what exactly institution and policy makers expected from them. However, scope and content of learning is argumentative while outcome is the attained objectives (Nusche, 2008). Learning is vast to be assesses by single instrument as some are easier to measure while other are complex and difficult (Baird, Andrich, Hopfenbeck, \& Stobart, 2017). This leads to the conclusion of "no single assessment can comprehensively measure all the important outcomes of higher education" (Nusche, 2008, p.8). In this case selecting appropriate and relevant assessment tool in the line with learning outcome corresponding with objectives should be emphasized. Likewise, Peterson, Vaughan, \& Perorazio (2001) underlined the correlation of students' assessment with effective learning and instruction, innovation and professional development of teachers.

\section{Authentic Assessment}

Recently, significance of authentic assessment has been found high attention which is believed to be responsive method (Sotiriadou, Logan, Daly, \& Guest, 2020, \& Reynisdóttir, 2016). The overall criticisms of traditional assessment that confined on attainment of certain knowledge and skills is believed to be insufficient in this dynamic and complex era. Thus, call for shifting to more wide and meaningful way of assessment known as authentic assessment (Mueller, 2005). According to the author, authentic learning and assessment concerns to students needs in the line with demands of real world. Likewise, Sotiriadou, Logan, Daly, \& Guest (2020) noted authentic assessments is assessment that is developed to measure student's capabilities to practice standard -driven knowledge, skills and actual challenges.

In the same vein, Reynisdóttir (2016) supported modifying of teaching process and assessment tools according to students' capabilities and needs is the main objective of instructors maintained authentic assessment. It is intentionally designed to examine how far students can apply the problem solving skills, demonstrate application of knowledge rather than only memorization (Sotiriadou, Logan, Daly, \& Guest, 2020 ,\&Zuzana Straková, 2015). For instance, in higher education continuous assessment can be categorized as authentic assessment as its principal goal is not enclosed to what is taught in the class but also to skills acquired for future life (Nusche, 2008). Moreover, authentic assessments' main focus is practicability in real world sceneries by giving students autonomy for presenting their abilities and competencies that enforce them to use higher order cognitive skills (Fook, \& Sidhu, 2010). Likewise, qualitative study by these researchers in Malaysia University indicated that authentic assessment is gained more acceptance from students and should be a better alternative to traditional assessment.

\section{Challenges of Assessment in Higher education}

For numerous reasons, HEIs are becoming a hub of diversified students (Laamanen et al., 2021). As a result, HEIs have been experiencing increasing accountability pressure to provide data on the quality of teaching and learning 
(Contreras-McGavin, \& Kezar, 2007; Nusche, 2008). This led to continuous disputes regarding assessment of students in higher education (Carless, 2015;Gilles, Detroz, \& Blais, 2011) as educators acknowledge as a gap between assessment methods employed and students learning (Douglas, Wilson \& Ennis, 2012; Webber, 2012). Besides, there is a continuous negotiation whether students' assessment support students learning in HEIs, which assessment techniques are effective and promote lifelong learning and the importance of feedback (Carless, 2015). However, there found imbalance between assessment tools used by teachers and quality of teaching (Postareff, Virtanen, Katajavuori, \& Lindblom-Ylänne, 2012). While several researches indicated assessment as tool for enhancing learning (Bonwell, 2010; Tosuncuoglu, 2018) contradictory some teachers utilized as an evaluation and grading device merely (Torrance, 2012). Since sustainability in education sector was declared by UNESCO in 1990s, many assessment tools for assessing HEIs has been developed through time that contain diversified assessment methodologies and indicators (Husaini, Jusoh, \& Kassim, 2018). Nevertheless, identifying reliable and suitable ways of collecting evidence regarding students learning was the main challenge confronting for early assessment experts (Banta, 2002) which is still issue of debate. Borghouts, Slingerland, \& Haerens (2017) noted there may be still a gap of alignment between intended learning outcomes and what essentially is being assessed.

Not differently, HEIs assessment methods has been criticized by over emphasizes on inputs, research activities, articles and journals published, which cannot be the real indicators of the actual knowledge and skills students acquired (Nusche, 2008). In the line with this, several studies stated that in HEIs there is mismatch between content taught and assessment practices employed (Fook, \& Sidhu, 2010). Nusche (2008) recommended that assessments should develop tools of collecting information for comparable learning outcomes on what students actually gain during their studies in HEIs that contributes to educational quality. Beside researchers suggested the replacement of traditional assessment methods but many HEIs yet struggle to implement (Mueller, 2005) parallel to demands of current skill and competency assessment techniques (Fook, \& Sidhu, 2010). Ahea (2016) noticed that traditional form of assessment with inadequate feedback is still continuing to be used in HEIs that less satisfies students' needs for nurturing learning experience of the current era.

\section{Conclusion}

Generally assessment is a process of collecting information about students' understanding, knowledge and skills against the intended objectives to be attained. The main objective of assessment is not merely confined for grading or evaluating students but improving and enhancing learning. It is also recognized as potent that can foster or inhibit students learning (Ghaicha, 2016). As a normal norm in HEIs students are commonly assessed by instructors or members of the faculty who taught the course under assessment however, for many instructors student assessment is one of challenging and toughest aspect that escalates numerous arguments (Bryan, \& Clegg, 2019). Study by Kezar (2013) revealed, dearth of faculty support as a major assessment implementation barriers which underline the vital role of leadership for effective assessment application. To meet this operation several approaches of assessment with certain fundamental principles has been developed through time, amongst which gets more attention recently is authentic assessment. Advocates of this approach stated the significance of consulting students for developing assessment tools as they are the main clients in the globalized era. Moreover, the slow switching of traditional way is not focused on students' needs and also puts less emphasizes on feedback. Though the significance of feedback is apparent, however many studies claim students are not receiving consistent, ample and timely feedback in higher education which requires high attention.

\section{Recommendation}

After reviewing several research studies this paper came with the following recommendations as the main areas that require careful consideration for effective assessment in HEIs. Here are listed below;

- Authentic assessment should be given high emphasized in higher education.

- Faculty members should involve in policy development for authentic assessment. 
- Coherent assessment tools should be developed.

- Professional development programs should target on assessment areas so as faculty to undertake learning outcomes assessment.

- Students' needs should be considered for developing assessment tools.

- Feedback should be consistent and clearly articulated.

\section{Remarks}

- $\quad$ Limited research studies available concerning assessment in higher education (Ghaicha, 2016).

- Dearth research on the connection between theories of learning and educational assessments (Baird, Andrich, Hopfenbeck, \& Stobart, 2017).

- Design of well-developed authentic assessments is less understood (Sotiriadou, Logan, Daly, \& Guest, 2020).

- Despite the significance of authentic assessment, there are still limited studies done that calls more research regarding the area (Reynisdóttir, 2016).

- Assessment in higher education in general and formative assessment particularly needs attention (Torrance, 2012).

\section{References}

Adam, S. (2004, July). Using learning outcomes. In Report for United Kingdom Bologna Seminar (pp. 1-2).

Ahea, M. (2016). The Value and Effectiveness of Feedback in Improving Students' Learning and Professionalizing Teaching in Higher Education. Journal of Education and Practice, 7(16), 38-41.

Ajayi, V. (2018). Difference between assessment, measurement and evaluation in science education. Retrieved on 05th, July.

Allan, J. (1996). Learning outcomes in higher education. Studies in higher education, 21(1), 93-108.

Altbach, P. G. (2015). AHELO: the myth of measurement and comparability. International Higher Education, (82), $2-3$.

Arustamyan, Y., Siddikova, Y., Sadullaeva, N., Solieva, M., \& Khasanova, N. (2020). Assessment of Educational Process and its Organization. International Journal of Psychosocial Rehabilitation, 24, 573-578.

Baird, J. A., Andrich, D., Hopfenbeck, T. N., \& Stobart, G. (2017). Assessment and learning: Fields apart?. Assessment in Education: Principles, Policy \& Practice, 24(3), 317-350.

Banta, T. W. (Ed.). (2002). Building a scholarship of assessment. John Wiley \& Sons.

Banta, T. W., \& Palomba, C. A. (2014). Assessment essentials: Planning, implementing, and improving assessment in higher education. John Wiley \& Sons.

Borghouts, L. B., Slingerland, M., \& Haerens, L. (2017). Assessment quality and practices in secondary PE in the Netherlands. Physical Education and Sport Pedagogy, 22(5), 473-489.

Brown, H. D., \& Abeywickrama, P. (2010). Language assessment: Principles and classroom practices (Vol. 10). White Plains, NY: Pearson Education.

Bryan, C., \& Clegg, K. (Eds.). (2019). Innovative assessment in higher education: A handbook for academic practitioners. Routledge.

Carless, D., Salter, D., Yang, M., \& Lam, J. (2011). Developing sustainable feedback practices. Studies in higher education, 36(4), 395-407.

Carless, D. (2015). Excellence in university assessment: Learning from award-winning practice. Routledge.

Contreras-McGavin, M., \& Kezar, A. J. (2007). Using qualitative methods to assess student learning in higher education. New Directions for Institutional Research, 2007(136), 69-79.

Douglas, M., Wilson, J., \& Ennis, S. (2012). Multiple-choice question tests: a convenient, flexible and effective learning tool? A case study. Innovations in Education and Teaching International, 49(2), 111-121. 
Ewell, P. (2007). Applying learning outcomes concepts to higher education: An overview. A report prepared for the University of Hong Kong Grants Committee. Boulder, Colorado: National Center for Higher Education Management Systems (NCHEMS).

Fook, C. Y., \& Sidhu, G. K. (2010). Authentic assessment and pedagogical strategies in higher education. Journal of social sciences, 6(2), 153-161.

Gerritsen-van Leeuwenkamp, K. J., Joosten-ten Brinke, D., \& Kester, L. (2019). Students' perceptions of assessment quality related to their learning approaches and learning outcomes. Studies in Educational Evaluation, 63, 72-82.

Ghaicha, A. (2016). Theoretical Framework for Educational Assessment: A Synoptic Review. Journal of Education and Practice, 7(24), 212-231.

Gilles, J., P. Detroz, P, \& Blais, J. (2011). An international online survey of the practices and perceptions of higher education professors with respect to the assessment of learning in the classroom. Assessment \& Evaluation in Higher Education. 36(6), 719-733.

Gronlund, N. (2006). Assessment of Student Achievement. Third Custom Edition for the University of Alberta. Toronto: Pearson Education, Inc.

Guangul, F. M., Suhail, A. H., Khalit, M. I., \& Khidhir, B. A. (2020). Challenges of remote assessment in higher education in the context of COVID-19: a case study of Middle East College. Educational Assessment, Evaluation and Accountability, 1-17.

Guetterman, T. C., \& Mitchell, N. (2016). The role of leadership and culture in creating meaningful assessment: A mixed methods case study. Innovative Higher Education, 41(1), 43-57.

Hernández, R. (2012). Does continuous assessment in higher education support student learning?. Higher education, 64(4), 489-502.

James, M. (2010). Educational assessment: overview. International Encyclopedia of Education:, 3(1), 161-171.

Kizlik, B. (2012). Measurement, assessment, and evaluation in education. Retrieved October, 10, 2015.

Koka, R., Jurāne-Brēmane, A., \& Koḳe, T. (2017). Formative Assessment in Higher Education: From Theory to Practice. European Journal of Social Science Education and Research, 4(1), 28-34.

Kuh, G. D., Jankowski, N., Ikenberry, S. O., \& Kinzie, J. L. (2014). Knowing what students know and can do: The current state of student learning outcomes assessment in US colleges and universities. Champaign, IL: National Institute for Learning Outcomes Assessment.

Laamanen, M., Ladonlahti, T., Uotinen, S., Okada, A., Bañeres, D., \& Koçdar, S. (2021). Acceptability of the eauthentication in higher education studies: views of students with special educational needs and disabilities. International Journal of Educational Technology in Higher Education, 18(1), 1-17.

Montgomery, J. R. (2008). Uses of Formal and Informal Assessments of English Language Learners in a Language Experience Class, School Year 2007-2008. Online Submission.

Mueller, J. (2005). The authentic assessment toolbox: enhancing student learning through online faculty development. Journal of Online Learning and Teaching, 1(1), 1-7.

Navarrete, C. (1990). Informal Assessment in Educational Evaluation: Implications for Bilingual Education Programs.

Nusche, D. (2008), "Assessment of Learning Outcomes in Higher Education: a comparative review of selected practices", OECD Education Working Papers, No. 15, OECD publishing, () OECD.

Palomba, C. A., \& Banta, T. W. (1999). Assessment Essentials: Planning, Implementing, and Improving Assessment in Higher Education. Higher and Adult Education Series. Jossey-Bass, Inc., Publishers, 350 Sansome Street, San Francisco, CA 94104.

Peterson, M. W., Vaughan, D. S., \& Perorazio, T. E. (2001). Student assessment in higher education: A comparative study of seven institutions. Ann Arbor, MI: University of Michigan, National Center for Postsecondary Improvement. 
Postareff, L., Virtanen, V., Katajavuori, N., \& Lindblom-Ylänne, S. (2012). Academics’ conceptions of assessment and their assessment practices. Studies in Educational Evaluation, 38(3-4), 84-92.

Rawlusyk, P. E. (2018). Assessment in higher education and student learning. Journal of Instructional Pedagogies, 21, 1-34.

Reynisdóttir, B. B. (2016). The Efficacy of Authentic Assessment: A Practical Approach to Second Language Testing (Doctoral dissertation).

Royce Sadler, D. (2012). Assessment, evaluation and quality assurance: Implications for integrity in reporting academic achievement in higher education. Education Inquiry, 3(2), 201-216.

Serban, A. M. (2004). Assessment of student learning outcomes at the institutional level. New directions for community colleges, 2004(126), 17-27.

Sotiriadou, P., Logan, D., Daly, A., \& Guest, R. (2020). The role of authentic assessment to preserve academic integrity and promote skill development and employability. Studies in Higher Education, 45(11), 21322148.

Taras, M. (2005). Assessment-summative and formative-some theoretical reflections. British journal of educational studies, 53(4), 466-478.

Taras, M. (2008). Issues of power and equity in two models of self-assessment. Teaching in Higher Education, 13(1), 81-92.

Torrance, H. (2012). Formative assessment at the crossroads: Conformative, deformative and transformative assessment. Oxford Review of Education, 38(3), 323-342.

Tosuncuoglu, I. (2018). Importance of Assessment in ELT. Journal of Education and Training Studies, 6(9), 163167.

Tractenberg, R. E. (2020). The Assessment Evaluation Rubric: Promoting learning and learner-centered teaching in higher education.1-21.

Tremblay, K., Lalancette, D., \& Roseveare, D. (2012). Assessment of higher education learning outcomes: Feasibility study report, volume 1 design and implementation. Paris, France: Organisation for Economic Co-operation and Development.

Webber, K. L. (2012). The use of learner-centered assessment in US colleges and universities. Research in Higher Education, 53(2), 201-228.

Zlatkin-Troitschanskaia, O., \& Shavelson, R. J. (2019). Advantages and challenges of performance assessment of student learning in higher education. British Journal of Educational Psychology, 89(3), 413-415. 